Link article (Style APA): Blynova, O. Ye. \& Ursulenko O. B. (2020). The features of the influence of urban identity on the social and psychological adaptation of students. Insight: the psychological dimensions of society, 3, 70-83. DOI: 10.32999/2663-970X/2020-3-5

Link article (Style DSTU 8302: 2015): Blynova, O. Ye. \& Ursulenko O. B. The features of the influence of urban identity on the social and psychological adaptation of students. Insight: the psychological dimensions of society, 2020, 3, 70-83. DOI: 10.32999/2663-970X/2020-3-5

UDC 316.6: 159.923.2

\title{
The features of the influence of urban identity on the social and psychological adaptation of students
}

\author{
Особливості впливу міської ідентичності \\ на соціально-психологічну адаптацію студентської молоді
}

Received: May 05, 2020 Accepted: June 08, 2020

Blynova OlenaYevgenivna

Doctor of Psychological Sciences, Full Professor,

Department of General and Social Psychology

Kherson State University, Ukraine elena.blynova@gmail.com, ORCID 0000-0003-3011-6082

Ursulenko Olena Borysivna Graduate student

Department of General and Social Psychology

Kherson State University, Ukraine khersonskarada@gmail.com, ORCID 0000-0001-5423-3334

\section{Блинова Олена Євгенівна}

доктор психологічних наук, професор кафедра загальної та соціальної психології Херсонський державний університет, Україна elena.blynova@gmail.com, ORCID 0000-0003-3011-6082

Урсуленко Олена Борисівна аспірантка

кафедра загальної та соціальної психології Херсонський державний університет, Україна khersonskarada@gmail.com, ORCID 0000-0001-5423-3334

\begin{abstract}
The purpose is to clarify the influence of the level of maturity of the urban identity on the social and psychological adaptation of students and satisfaction with life. Methods. The following methods were used in the empirical research: Urban Identity Questionnaire (S. O. Litvinova, O. I. Muravyova); Questionnaire of Social and Psychological Adaptation (C. Rogers \& R. Diamond, adapted by O. K. Osnytsky); The Satisfaction with Life Scale of E. Diener adapted by D. O. Leontiev, Ye. M. Osin). Results. The article includes different theoretical viewpoints and scientific approaches to the substantiation of the concept "urban identity". The structure of urban identity consists of cognitive, emotional and behavioral-regulatory components. The research shows the influence of mature identity on the social adaptation under urban conditions. The authors make the social
\end{abstract}

\begin{abstract}
Анотація
Мета: з'ясувати вплив рівня сформованості міської ідентичності на соціально-психологічну адаптацію студентської молоді та задоволеність життям. Методи. В емпіричному дослідженні застосовано методики: Опитувальник ідентичності 3 містом (С. О. Літвінова, О. І. Муравьова); Опитувальник соціально-психологічної адаптації (К. Роджерс, Р. Даймонд в адаптації О. К. Осницького); Шкала задоволеності життям Е. Дінера в адаптації Д. О. Леонтьєва, Є. М. Осіна. Результати. В статті наведено різні теоретичні погляди та наукові підходи щодо обгрунтування поняття “міська ідентичність". У структурі міської ідентичності виокремлено когнітивний, емоційний та поведінково-регулятивний компоненти. Показано значення сформованої міської ідентичності на соціальну адаптацію в умовах міста. Зроблено соціально-психологічне аналізування відмінностей
\end{abstract}


and psychological analysis of differences between the urban and countryside lifestyles; they find out that urban lifestyle is based on a high spatial, professional and social mobility of urbanites. It is emphasized that urban identity has an axiological and logical nature as it sets norms and rules, which regulate human behavior while actualizing in different situations of social interaction. The empirical research clarified the features of the manifestation of students' urban identity, its influence on the social and psychological adaptation of students, carries out a comparative analysis between a group of students who are original residents of the city and a group of students who moved into the city from the countryside to study at the university. Conclusions. The findings of the empirical research confirm the differences in terms of the social and psychological adaptation between the group of "urbanites", i.e. students who were born and live in the city and the group of "country people" who moved into the city to study at the university. By using the correlation analysis, the authors prove the interdependence between the level of maturity of urban identity of students (cognitive, emotional and behavioral-regulatory components) and progress of social and psychological adaptation in the city. The research prospects are the development of means of psychological aid for the adaptation of students who come to the city to study at the higher education institutions.

Keywords: cognitive, emotional, behavioral-regulatory components of urban identity, life satisfaction, feeling of belonging to city, emotional attachment to city.

\section{Introduction}

Active changes within the modern society determine the evolution of human movements, in particular, labor, shuttle and educational migration that leads to the interpenetration and mutual influence of traditional rural and urban cultures. The very territorial communities provide the first experience of group comprehension of reality identifying the primary factors of socialization, the formation of values, needs, attitudes, norms (Blynova et. al., 2019; Dias \& Ramadier, 2015).

To understand the social human behavior, the knowledge of the development of urban identity as a component of the social identity of the personality is of importance (Bernardo \& Palma-Oliveira, 2013). However, there is a lack of complex psychological researches of this phenomenon and its position in a wider structure of the mechanisms regulating social behavior. міського та сільського способу життя; з'ясовано, що міський спосіб життя грунтується на високій просторовій, професійній та соціальній мобільності містян. Підкреслено, що міська ідентичність має ціннісну та смислову природу, адже, актуалізуючись у різних ситуаціях соціальної взаємодії, вона починає транслювати норми та правила, що регулюють поведінку людини. В емпіричному дослідженні з'ясовано особливості прояву міської ідентичності студентської молоді, іiї вплив на соціально-психологічну адаптацію студентів, проведено порівняльний аналіз між групами студентів, які $\epsilon$ корінними жителями міста та групою студентів, які приїхали до міста із сільської місцевості для навчання в університеті. Висновки. Результати емпіричного дослідження засвідчили наявність відмінностей за показниками соціально-психологічної адаптації між групою «містян», тобто студентів, які народились та проживають у місті, та групою "селян”, які приїхали до міста та навчаються в університеті. За допомогою кореляційного аналізу доведено взаємозалежність між рівнем сформованості міської ідентичності студентської молоді (когнітивного, емоційного, поведінково-регулятивного компонентів) та успішністю соціально-психологічної адаптації у місті. Перспективами дослідження є розробка засобів психологічної допомоги в адаптації студентів, які приїжджають до міста для навчання у закладах вищої освіти.

Ключові слова: когнітивний, емоційний, поведінково-регулятивний компоненти міської ідентичності, задоволеність життям, почуття належності до міста, емоційна прив'язаність до міста.

\section{Вступ}

Активні зміни у сучасному суспільстві детермінують розвиток переміщень людей, зокрема, трудова, маятникова та освітня міграція, що призводить до взаємопроникнення та взаємовпливу традиційної сільської та міської культур. Саме територіальні спільноти надають перший досвід групового осмислення реальності, визначаючи первинні чинники соціалізації, формування цінностей, потреб, установок, норм (Blynova et. al., 2019; Dias \& Ramadier, 2015).

Для розуміння соціальної поведінки людини важливими є знання про розвиток міської ідентичності як компонента соціальної ідентичності особистості (Bernardo \& Palma-Oliveira, 2013). Проте, комплексних психологічних досліджень цього феномену та його місця у більш широкій структурі механізмів регуляції соціальної поведінки, на сьогодні бракує. 
The factor of territorial, in particular urban identity, should be taken into account when studying psychological issues associated with the adaptation to other living conditions in a new social group: how does this process run over time, how does the essence of territorial identity change, when and under the influence of which factors is the identity formed in the context of a new place of residence and its inhabitants, and how is the identity with the home town (or village) transformed.

The issue of the influence of urban identity on the progress of social adaptation is relevant while exploring the processes of educational migration when the future students come to the city form countryside to study at the university (Blynova, 2018). Students from the countryside and small towns, who move to study at the university in the city, prone to an emotional perception of the situation, experience a psychological crisis due to age, social and psychological characteristics of the personality. The need for social and psychological adaptation is caused by the change in the social environment, lifestyle and activities of students as well as the availability of a regulatory crisis of adolescence, which is associated with professional and personal identity.

Hypothesis: The urban environment, depending on its perception and maturity of urban identity of a personality, can be a potential facilitating the implementation of personal significant purposes and values or an obstacle to self-realization and a stress factor.

The purpose is to clarify the influence of the level of maturity of urban identity on the social and psychological adaptation of students and life satisfaction.

\section{The research methodology}

The main criteria for the division of urban and rural societies are the population, area of settlements, predominant types of work, specifics of lifestyle and lifequality, social situation and financial status of people, cultural and educational level of residents, development of basic social institutions, a complex of socio-economic and welfare conditions. F. Tönnies, a German sociologist, marked the differences between the concepts "community", which is applied to the rural area, and "society", which mainly characterizes the industrial urban society. The character
Фактор територіальної, зокрема, міської ідентичності, слід враховувати при вивченні психологічних проблем, що пов'язані з адаптацією до інших умов життя у новій соціальній групі: як розгортається цей процес у часі, як змінюється зміст територіальної ідентичності, коли і під впливом яких чинників формується ідентичність 3 новим місцем проживання та його жителями, та трансформується ідентичність з рідним містом (або селом)

Проблема впливу міської ідентичності на успішність соціальної адаптації $є$ актуальною при вивченні процесів освітньої міграції, коли майбутні студенти із сільської місцевості прибувають до міста для навчання в університеті (Блинова, 2018). Студенти із сільської місцевості та невеличких містечок, які приїхали для навчання в університеті в місто, схильні до емоційного сприйняття ситуації, відчувають психологічну кризу внаслідок вікових, соціальних та психологічних особливостей особистості. Потреба у соціально-психологічній адаптації зумовлена зміною соціального оточення, способу життя та діяльності студентів, а також наявністю нормативної кризи юнацького віку, що пов'язана з професійним та індивідуальним самовизначенням.

Гіпотеза. Міське середовище, залежно від його сприйняття та залежно від сформованості міської ідентичності особистості, може бути потенціалом, що сприяє реалізації суб'єктивно значущих цілей та цінностей, або перешкодою для самореалізації та стресовим чинником.

Мета: з'ясувати вплив рівня сформованості міської ідентичності на соціально-психологічну адаптацію студентської молоді та задоволеність життям.

\section{Методологія дослідження.}

Основними критеріями розділення міського та сільського соціумів називають чисельність населення, розміри населених пунктів, переважаючі види праці, специфіку способу та якість життя, соціальне положення та матеріальне становище людей, культурний та освітній рівень жителів, розвиток базових соціальних інститутів, комплекс соціально-економічних та культурно-побутових умов. Ще німецький соціолог Ф. Тьонніс говорив про відмінності понять «община», яке застосовується до сільської громади, та поняття «суспільство», яке більшою мірою характеризує індустріальне міське суспільство. Характер домінуючих в громаді міжособистісних відносин дозволяє відзначити інтимність та довірливість між людьми, 
of interpersonal relations predominant within society makes it possible to highlight intimacy and trustfulness between people, fidelity, and life which meets the community-based principles. The urban community is characterized by rational relations, prudence, benefit orientation, alienation, anonymity, loss of personal connections (Baranova, 2012: 195).

Urban identity is a result of the process of social categorization which is grounded on the individual's belonging to the urban community (Mykliaeva, Rumiantseva, 2011). The social in-group (membership group) for the individual is own urban community, and out-group is people who live in the rural area. Thus, the comprehension of norms and values of the city dweller is opposed to the rural way of life and expressed in the identification formula "I'm an urbanite".

S. Milgram put forward the experimental study of the urban specifics. He introduced the concept "reloading" as a social phenomenon which characterizes the processes of social urban communication. S. Milgram identified the following aspects of communication of urbanites: superficial forms of participation in interaction with other people; availability of social means of protection and selection of information by the individual, which allows urbanites to avoid information overload (Milgram, 2000).

The city has many attractive elements, namely, the differentiation of business performance, leisure, education, living conditions, mass media, as well as services, communications, transport, etc., that creates cultural diversity and alternative; mobility as a psychological attitude of the individual to the possibility of changing profession, social ties, updating information in various areas of urban life (Ujanga \& Zakariya, 2015).

S. Milgram stated: "Cities have great appeal because of their variety, eventfulness, possibility of choice, and the stimulation of an intense atmosphere that many individuals find a desirable background to their lives.The city provides options that no other social arrangement permits (Milgram, 2002: 5).

The city lifestyle is based on a sufficiently high spatial, professional and social mobility of urbanities. The city life leads to the involvement of the personality in different groups that compose the urban community. The diversity of activity types in the city creates a potential opportunity прив'язаність, життя у відповідності до громадських принципів. Міська спільнота характеризується раціональними відносинами, розважливістю, орієнтацією на отримання користі, відчуженням, анонімністю, втратою особистих зв'язків (цит. за Баранова, 2012 : 195).

Міська ідентичність $€$ результатом процесу соціальної категоризації, основою для якої $\epsilon$ належність людини до міської спільноти (Микляева, Румянцева, 2011). Соціальною ін-групою (групою членства) для людини $\epsilon$ власна міська спільнота, аут-групою - люди, що живуть у сільській місцевості. Таким чином, осмислення норм та цінностей міського жителя протиставляється сільському способу життя та виражається в ідентифікаційній формулі "Я-містянин".

С. Мілграм запропонував експериментальне вивчення специфіки міста. Він ввів поняття «перевантаження» як соціального феномену, що характеризує процеси соціальної комунікації у місті. До особливостей комунікації між жителями міста С. Мілграм відносить: поверхові форми участі у взаємодії з іншими людьми; наявність соціальних засобів захисту та відбору індивідом інформації, що дозволяє уникнути містянам інформаційного перевантаження (Милграм, 2000).

Місто має багато привабливих елементів, а саме, диференціація виробничої діяльності, дозвілля, освіти, побутових умов, засобів масової інформації, а також обслуговування, зв'язку, транспорту тощо, що викликає культурну різноманітність та вибір; мобільність як психологічна установка особистості на можливість зміни професії, соціальних зв'язків, оновлення інформації у різних сферах міського життя (Ujanga \& Zakariya, 2015).

С. Мілграм зазначає: "Міста мають значну привабливу силу через їх розмаїття, насиченості подіями, наявності можливості вибору та стимулюючого впливу їх напруженої атмосфери, що для багатьох людей є бажаним життєвим фоном. Велике місто надає великі можливості для комунікації; надає такі можливості вибору, які не може запропонувати жодна соціальна структура" (Милграм, 2002 : 5).

Міський спосіб життя грунтується на достатньо високій просторовій, професійній та соціальній мобільності містян. Життя у місті зумовлює включення особистості у різноманітні групи, що складають міську спільноту. Різноманітність видів діяльності у місті створює потенційну можливість для більш універсального розвитку особистості. Значна численність населення у містах 
for a more universal development of the personality. A high number population in cities results in the advanced autonomy and, at the same time, a constant disturbance of the boundaries of personal space of a particular resident. The ambiguity of behavior standards, a wide range of roles generate the permanent need to choose an individual strategy of behavior, as well as a high level of variability and behavior alternativeness (Diahyleva, Zhuravleva, 2012).

Kh. E. Steinbach and, V. I. Yelensky call that sort of a feature of interpersonal communication in cities the effect of "broken communication chain", which involves a low level of feedback on the behavior of the interlocutor, the weak expression of social support and social solidarity. In towns or villages, there is a neighbor mutual help which is a basis of considerably strong social support (Steinbach, Yelensky, 2004).

When characterizing a standardized behavior, one refers to the effect of de-individualization typical for cities that causes the reduction of social control over each particular individual. Moreover, the cities are characterized by a lack of personality which increases the anonymity of individual actions and allows citizens to infringe standardized behavior more often. A. V. Miklyaieva and P. V. Rumyantseva note that the decline in social control also results in the emergence and manifestation of various behavioral deviations that lay behind the various urban communities. Due to the scope of behaviors, urbanites are generally more tolerant of behavior violating the norm than residents of small towns or villages. In contrast, there are specific, clear norms and standards of conduct in small towns and villages. The social control is much higher than in big cities, and any violation of standardized behavior is condemned (Miklyaieva, Rumyantseva, 2011).

Thus, the residency in a certain urban space determines the formation and development of urban identity. However, the city area is not the only factor as the maintenance of urban identity is possible outside a particular city, because city boundaries are penetrable to the mobility of its inhabitants. A man can keep the personal urban identity being outside the city for a while.

N. S. Diahilieva, L. A. Zhuravlova consider "an urbanite" as the holistic system and mark his constituent elements, as follows: urbanite as an individual; urbanite as a representative of various призводить до підвищення автономності та водночас до постійного порушення меж особистого простору конкретного жителя. Неоднозначність норм поведінки, широкий діапазон ролей породжують постійну необхідність вибору власної стратегії поведінки, а також високий рівень варіативності та альтернативності поведінки (Дягилева, Журавлева, 2012).

X. Е. Штейнбах та В. I. Єленський називають таку особливість міжособистісних комунікацій у містах ефектом "рваного комунікативного ланцюга”, який полягає у низькому рівні зворотних реакцій на поведінку партнера по взаємодії, слабкій виразності соціальної підтримки та соціальної солідарності. У невеличких містечках або селах існує сусідська взаємодопомога, що лежить в основі достатньо сильної соціальної підтримки (Штейнбах, Еленский, 2004).

Характеризуючи нормативну поведінку, вказують на ефект деіндивідуалізації, який характерний для великих міст, що призводить до зниження соціального контролю за кожною конкретною людиною. Крім того, для великих міст характерною єзнеособленість, яка підвищує анонімність вчинків окремої людини та дозволяє містянам частіше виходити за межі нормативної поведінки. А. В. Мікляєва та П. В. Румянцева відмічають, що зниження соціального контролю також призводить до виникнення та прояву різних поведінкових девіацій, які лежать в основі різноманітних міських спільнот. Завдяки такій різноманітності поведінкових проявів жителі міст в цілому є більш толерантними до поведінки, яка виходить за межі норм, порівняно із населенням містечок або сел. У невеличких містечках або селах, навпаки, виникають специфічні, чіткі норми та правила поведінки. Соціальний контроль $€$ значно вищим, ніж у великих містах, будь-який вихід за межі нормативної поведінки засуджується (Микляева, Румянцева, 2011).

Отже, проживання у певному міському просторі детермінує формування та розвиток міської ідентичності. Проте, міська територія не $є$ єдиним чинником, оскільки підтримання міської ідентичності можливо і поза конкретним містом, оскільки межі міста є проникними для мобільності його жителів. Людина, перебуваючи невелику кількість часу за межами міста, здатна зберігати свою міську ідентичність.

Н. С. Дягілєва, Л. А. Журавльова говорять про «містянина» як про цілісну систему, та виділяють такі його складові елементи: містянин як особистість; містянин як представник різних соціальних груп; містянин як вираження 
social groups; urbanite as an expression of certain specific features that are generated by the city. The latter statement refers to the urban identity, i.e. treatment of an urbanite as a representative of the urban social group (Diahilieva, Zhuravlova, 2012).

The literature contains different criteria which make it possible to analyze the urban identity of an individual. They consist of the territorial criterion (city boundaries which are perceived subjectively); time criterion (chronology of the city life which is perceived subjectively); behavioral criterion (demonstration of behavior patterns typical to the urban community); psychosocial criterion (demonstration of the lifestyle typical to the urban community); social criterion (subjective experience of uniformity of the urban community); ideological criterion (the use of cultural and ideological principles rendered by the urban community) (Belanche, Casalys \& Flavian, 2017).

In other words, the urban identity should be interpreted in the aspect of social identity of a person. Therefore, S. O. Litvinova and O. I. Muravyova believe the residents of the one city, who compose the urban community, can be considered as followers of similar visions of their city and other cities: ideas about city norms and rules of conduct; collective historical memory; experiences related to specific places and territories; ideas about the normative way of life of citizens; notions of the normative ways of interaction and models of behavior (Litvinova, Muravyova, 2018).

Urban identity is formed in the process of interaction with social reality in which this reality is subjectively realized under the current system of relations and needs of an individual. Thus, urban identity has a notional nature as by actualizing in different situations of the social interaction it begins to lay down the norms and rules of regulation of human behavior. In other words, an urbanite has "personal city" (associated with individual experiences and memories, places which have intimate significance) and "our city" (this is a collective image of the city the subject of which is an urban community, and its members identify themselves with values of the specific territory (Miklyaeva, Rumyantseva, 2011).

It is proved, in particular, by the study of I. H. Hubeladze that there are differences in the perception of a typical urbanite and a typical villager. The author got a generalized "portrait" - певних специфічних рис, які породжуються містом. В останньому випадку як раз мова йде про міську ідентичність, тобто розгляд жителя міста як представника міської соціальної спільноти (Дягилева, Журавлева, 2012).

В літературі пропонуються різні критерії, що дозволяють проаналізувати міську ідентифікацію окремої людини. До таких критеріїв належать:територіальний критерій (межі міста, які сприймаються суб'єктивно); часовий критерій (хронологія міського життя, яка сприймається суб'єктивно); поведінковий критерій (демонстрація типових для міської спільноти моделей поведінки); психосоціальний критерій (демонстрація типового для міської спільноти способу життя); соціальний критерій (суб'єктивне переживання однорідності міської спільноти); ідеологічний критерій (застосування культурних та ідеологічних значень, що транслюються міською спільнотою) (Belanche, Casalys \& Flavian, 2017).

Тобто міську ідентичність необхідно трактувати в аспекті соціальної ідентичності людини. Тому С. О. Літвінова, О. І. Муравьова вважають, що жителів одного міста, які складають міську спільноту, можна розглядати як носіїв схожих уявлень про своє місто та про інші міста: уявлення про міські норми та правила поведінки; колективну історичну пам'ять; переживання, що пов'язані з конкретними місцями та територіями; уявлення про нормативний спосіб життя містян; уявлення про нормативні способи взаємодії та моделі поведінки (Литвинова, Муравьова, 2018).

Міська ідентичність формується у процесі взаємодії із соціальною реальністю, в якій ця реальність суб'єктивно усвідомлюється у відповідності до існуючої у людини системи життєвих відносин та потреб. Тобто міська ідентичність має смислову природу, адже, актуалізуючись у різних ситуаціях соціальної взаємодії, вона починає транслювати норми та правила, що регулюють поведінку людини. Іншими словами, у містянина існує “своє місто" (пов'язане із суб'єктивними переживаннями та спогадами, 3 місцями, які мають особистісне значення), i "наше місто" (це колективний образ міста, суб’єктом якого є міська громада, члени якої ідентифікують себе із цінностями даної території) (Микляева, Румянцева, 2011).

Доведено, зокрема у дослідженні I. Г. Губеладзе, що $\epsilon$ відмінності у сприйнятті типового містянина та типового селянина. Авторкою був отриманий узагальнений «портрет» - образ жителів міського та сільського соціумів. Група 
an image of the residents of urban and village societies. The group "city residents" is people of education (they are intelligent, interested in culture, art and use modern technologies), who are constantly in a hurry (they are mobile, dynamic, and eat on the go, etc.), busy and fussy. City residents are private, unsociable, distrustful, indifferent, and individualistic; they are under constant stress, nervous, unbalanced, and tired. They are characterized by independence and sense of purpose.Urbanites look fashionable, well-groomed and well-dressed. The group "village residents" is characterized by naiveté and low educational level. A distinctive feature is a hard-working nature. Slowness, regularity, calm is peculiar to this group. Village residents are open-hearted, friendly, kind, sociable, trusting (Hubeladze, 2015).

Based on the theoretical analysis of scientific literature, one can suggest a village resident who comes to the city (for instance, it refers to the educational migration when village youth studies at the university) will face some challenges in the social adaptation.

\section{Participants}

67 people consisted of freshmen and sophomores of the intramural form of study from different faculties and specialties of Kherson State University joined the empirical study. Among the respondents, 28 people $(41.8 \%)$ were born and grew in Kherson, 39 students (58.2\%) came to Kherson to study at the university and parents live in villages or towns of the region; the students who now live in a dormitory.

\section{Procedure and tools}

To determine the urban identity, the authors use Urban Identity Questionnaire of S. O. Litvinova, O. I. Muravyova (Litvinova, Muravyova, 2018). The questionnaire is conceptualized as the self-determination of an individual in the urban environment. The questionnaire contains not only the traditional dimensions of identity: cognitive, emotional, evaluative, which represent the self-identification with a particular place by a person, his attachment to it, evaluation of home city compared to other places, but also indicators that reflect a willingness to act in the interest of a city, its development, i.e. behavioral and activity aspects of identification.

The questionnaire has five scales that render the identity with a city under cognitive, emotional, “жителі міста" - освічені люди (ерудовані, цікавляться культурою, мистецтвом, застосовують сучасні технології), які постійно поспішають (мобільні, динамічні, їдять на ходу і т. ін.), зайняті та метушливі. Жителі міста $є$ замкненими, нетовариськими, недовірливими, байдужими, індивідуалістичними; перебувають у постійному стресі, нервові, неврівноважені, втомлені. Вони характеризуються самостійністю та цілеспрямованістю. Ззовні - модні, доглянуті, добре вдягнуті. Група “жителі села" характеризується простотою, низьким рівнем освіти. Виразна риса - працелюбність. Для цієї групи властивою $\epsilon$ неквапливість, розміреність, спокій. Селяни $\epsilon$ відкритими, товариськими, добрими, привітними, довірливими (Губеладзе, 2015).

На підставі теоретичного аналізу наукової літератури можна припустити, що сільський житель, який приїжджає у місто (наприклад, мова йде про освітню міграцію, коли молодь із села навчається в університетах міста), буде відчувати певні складнощі в соціальній адаптації.

\section{Учасники.}

В емпіричному дослідженні взяли участь студенти I-II курсів денної форми навчання Херсонського державного університету різних факультетів та спеціальностей у кількості 67 осіб. Серед респондентів 28 осіб (41,8\%) - ті, які народилися та виросли у Херсоні, 39 студентів (58,2 \%) приїхали у Херсон навчатися в університеті, батьки проживають в селах або невеликих містечках області; студенти зараз мешкають у гуртожитку.

\section{Процедура та інструменти.}

Для визначення міської ідентичності нами застосовано "Опитувальник ідентичності 3 містом" С.О. Літвінової, О. І. Муравьової (Литвинова, Муравьева, 2018). В опитувальнику ідентичність з містом концептуалізується як самовизначення людини у міському середовищі. Опитувальник містить у собі не тільки традиційні виміри ідентичності: когнітивні, емоційні, оцінні, які репрезентують сприйняття людиною себе частиною певного місця, іï̈ прив'язаність до нього, оцінку свого міста порівняно з іншими місцями, але й показники, що відображають готовність діяти в інтересах міста, його розвитку, тобто поведінковий та діяльнісний аспекти ідентифікації.

Опитувальник містить п'ять шкал, що відображають зміст ідентичності з містом за когнітивним, емоційним, оцінним та діяльнісно-поведінковим вимірам: 1) Почуття належності до міста та віра в його можливості; 2) Емоційна прив'язаність та почуття близькості; 3) Місто, 
evaluative and activity-behavioral dimensions: 1) Belonging to the city and belief in its possibilities; 2) Emotional attachment and feeling of closeness; 3) A city which has a unique nature; 4) Personal contribution to the city life; 5) Planning of the future, which is connected with the city. The questionnaire text is rendered into Ukrainian by language experts, and the name of a city is changed in the context of the study sample.

To diagnose the social and psychological adaptation, the authors use C. Rogers \& R. Diamond Questionnaire of Social and Psychological Adaptation (Carl R. Rogers, Rosalind F. Dymond) adapted by $\mathrm{O}$. K. Osnytsky. The questionnaire includes five basic scales (acceptance of others; internality; self-perception; emotional comfort; the pursuit of dominance) and one integral, which reflects the general index of adaptability/maladaptation. The method aims to find out the level of an individual's adaptability in the social area, and the factors of maladaptation are as follows: low level of self-perception; low level of acceptance of others, i.e. confrontation with them; emotional discomfort; externality; the pursuit of dominance.

To study the general level of satisfaction with life, the authors use Satisfaction With Life Scale (SWLS) of E. Diener, R. A. Emmons, R. J. Larsen and S. Griffin adapted by D. O. Leontiev, Ye. M. Osin (Leontiev, Osin, 2008).

The statistical processing of empirical data is carried out through the statistical programs "SPSS" v. 23.0 and "MS Excel"; it is applied the com- яке має унікальність; 4) Особистий внесок у життя міста; 5) Планування майбутнього, яке пов'язане із містом. Текст опитувальника було перекладено українською мовою фахівцями-експертами з мови, за смисловим контекстом назву міста було змінено для досліджуваної вибірки.

Для діагностики соціально-психологічної адаптації застосовано “Опитувальник соціально-психологічної адаптації” К. Роджерса, Р. Даймонд(CarlR.Rogers, RosalindF.Dymond) вадаптації О. К. Осницького (Осницкий, 2004). Опитувальник містить п'ять основних шкал (прийняття інших, інтернальність, самоприйняття, емоційна комфортність, прагнення до домінування) та одну інтегральну, яка відображає загальний показник адаптованості / дезадаптованості. Методика спрямована на з'ясування міри адаптованості особистості в соціальній сфері, чинниками дезадаптації можуть бути: низький рівень самоприйняття; низький рівень прийняття інших, тобто конфронтація з ними; емоційний дискомфорт; екстернальність; прагнення до домінування.

3 метою вивчення загального рівня задоволеності життям застосовано «Шкалу задоволеності життям» (Satisfaction With Life Scale, SWLS) E. Diener, R.A. Emmons, R.J. Larsen и S. Griffin в адаптації Д. О. Леонтьєва, Є. М. Осіна (Осин, Леонтьев, 2008).

Статистичну обробку емпіричних даних здійснено за допомогою статистичних програм "SPSS" v. 23.0 та "MS Excel”; застосовано порівняльний аналіз за допомогою t-критерію Ст'юдента та кореляційний аналіз).

Table 1. Average indicators and average squared differences under the scales of Urban Identity Questionnaire (S. O. Litvinova, O. I. Muravyova) ( $\mathrm{n}=67)$

Таблиця 1. Середні значення та середньоквадратичні відхилення за шкалами методики “Опитувальник ідентичності з містом" (С. О. Літвінова, О. І. Муравьова) (n = 67)

\begin{tabular}{|c|c|c|}
\hline $\begin{array}{c}\text { Scale name } \\
\text { Назва шкал } \\
\end{array}$ & M & SD \\
\hline $\begin{array}{l}\text { 1. Belonging to the city and belief in its opportunities } \\
\text { 1. Почуття належності до міста та віра в його можливості }\end{array}$ & 19.13 & 3.87 \\
\hline $\begin{array}{l}\text { 2. Emotional attachment and feeling of closeness } \\
\text { 2. Емоційна прив'язаність та почуття близькості }\end{array}$ & 21.48 & 3.64 \\
\hline $\begin{array}{l}\text { 3. A city which has a unique nature } \\
\text { 3. Місто, яке має унікальність }\end{array}$ & 14.56 & 2.31 \\
\hline $\begin{array}{l}\text { 4. Personal contribution to city life } \\
\text { 4. Особистий внесок у життя міста }\end{array}$ & 11.74 & 2.07 \\
\hline $\begin{array}{l}\text { 5. Planning of the future, which is connected with the city } \\
\text { 5. Планування майбутнього, яке пов'язане із містом }\end{array}$ & 8.49 & 1.76 \\
\hline
\end{tabular}

Note: ${ }^{*} \mathrm{M}$ - arithmetic mean; SD - mean square deviation. 
parative analysis through Student's t-test and correlational analysis.

\section{Results and discussions}

The results of students under the Urban Identity Questionnaire (S. O. Litvinova, O. I. Muravyova) are presented in table 1 .

The results show that indicators of all scales of the Urban Identity Questionnaire are at the average level. The scale "Belonging to the city and belief in its opportunities" demonstrates above than average value ( $M=19.13$; $S D=3.87)$. When comparing the test criteria, the scales "Emotional attachment and feeling of closeness" ( $\mathrm{M}=21.48$; $\mathrm{SD}=3.64$ ) and "A city that has a unique nature" $(\mathrm{M}=14.56 ; \mathrm{SD}=2.31)$ indicate the values above the average. Thus, the level of maturity of cognitive and emotional components of the urban identity of students is average and above average that is in line with the data of other scientists, for instance,

\section{Результати та дискусії.}

Результати студентів за "Опитувальником ідентичності 3 містом" (С. О. Літвінова, O. І. Муравьова) представлено у таблиці 1.

Результати показали, що значення всіх шкал “Опитувальника ідентичності з містом" знаходяться на середньому рівні. Шкала "Почуття належності до міста та віра в його можливості" показала трохи вищий за середньонормативні значення показник (M = 19.13; $\mathrm{SD}=3.87)$. При порівнянні зі шкалою тестових норм, вище за середні значення отримано за шкалами "Емоційна прив'язаність та почуття близькості" (M = 21.48; SD = 3.64); "Місто, яке має унікальність" (M = 14.56; $\mathrm{SD}=2.31)$. Таким чином, рівень сформованості когнітивного та емоційного компонентів міської ідентичності у студентської молоді є середнім та вище за середній, що узгоджується з даними інших дослідників, наприклад, Н. С. Дягилєвої, Л. А. Журавльової (Дягилева, Журавлева, 2012); С. О. Літвінової, О. І. Муравьової (Литвинова, Муравьева, 2018).

Table 2. Average values and average squared differences under the scales of Questionnaire of Social and Psychological Adaptation (C. Rogers, R. Dymond) adapted by O. K. Osnytsky and Satisfaction with Life Scale (E. Diener) adapted by D. O. Leontiev, Ye. M. Osin (n = 67)

Таблиця 2. Середні значення та середньоквадратичні відхилення за шкалами методики “Опитувальник соціально-психологічної адаптації” (К. Роджерс, Р. Даймонд в адаптації О. М. Осницького) та “Шкала задоволеності життям" (Е. Diener в адаптації Д. О. Леонтьєва, Є. М. Осіна) (n = 67)

\begin{tabular}{|c|c|c|c|c|c|c|}
\hline \multirow[t]{2}{*}{$\begin{array}{l}\text { Scale name } \\
\text { Назва шкал }\end{array}$} & \multicolumn{2}{|c|}{$\begin{array}{l}\text { Group } 1 \text { (original } \\
\text { residents of Kherson) } \\
\text { (n=28) } \\
\text { Група } 1 \text { (корінні } \\
\text { жителі Херсона) } \\
\text { (n = 28) }\end{array}$} & \multicolumn{2}{|c|}{$\begin{array}{l}\text { Group } 2 \text { (those who } \\
\text { came to Kherson to } \\
\text { study) (n=39) } \\
\text { Група } 2(\mathrm{Ti}, \text { хто } \\
\text { приїхали в Херсон } \\
\text { для навчання) } \\
\text { (n= 39) }\end{array}$} & \multirow[t]{2}{*}{$\begin{array}{c}\text { Student's } \\
\text { t-test } \\
\text { t-крит. } \\
\text { Ст'юдента }\end{array}$} & \multirow[t]{2}{*}{$\begin{array}{c}\text { Significance } \\
\text { level } \\
\text { Рівень } \\
\text { значущ. }\end{array}$} \\
\hline & $\mathbf{M}$ & SD & M & SD & & \\
\hline $\begin{array}{c}\text { Adaptability } \\
\text { Адаптивність }\end{array}$ & 137.23 & 21.74 & 128.07 & 17.69 & 7.96 & $\mathrm{p}<0.01$ \\
\hline $\begin{array}{c}\text { Self асcерtance } \\
\text { Самоприйняття } \\
\end{array}$ & 41.27 & 8.76 & 37.11 & 7.25 & 5.94 & $\mathrm{p}<0.01$ \\
\hline $\begin{array}{c}\text { Acceptance of others } \\
\text { Прийняття інших }\end{array}$ & 22.14 & 4.17 & 21.73 & 4.24 & - & - \\
\hline Emotionalcomfort & 28.17 & 5.36 & 24.09 & 4.87 & 7.30 & $\mathrm{p}<0.01$ \\
\hline $\begin{array}{c}\text { Internality } \\
\text { (internalcontrol) } \\
\text { Інтернальність } \\
\text { (внутрішній контроль) }\end{array}$ & 48.13 & 5.78 & 46.65 & 5.19 & - & - \\
\hline $\begin{array}{c}\text { The pursuit of dominance } \\
\text { Прагнення до } \\
\text { домінування }\end{array}$ & 13.16 & 2.41 & 14.27 & 2.35 & - & - \\
\hline $\begin{array}{c}\text { Life satisfaction } \\
\text { Задоволеність життям }\end{array}$ & 26.17 & 5.79 & 23.48 & 5.36 & 4.63 & $\mathrm{p}<0.01$ \\
\hline
\end{tabular}

Note: ${ }^{*} \mathrm{M}$ - arithmetic mean; SD - mean square deviation. 
The features of the influence of urban identity on the social and psychological adaptation of students

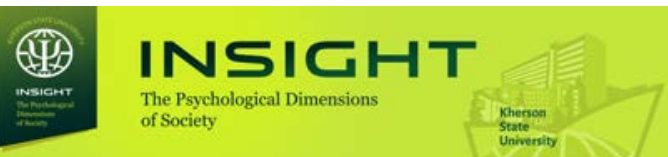

of N. S. Diahylieva, L. A. Zhuravlova (Diahilieva, Zhuravlova, 2012); S. O. Litvinova, O. I. Muravyova (Litvynova, Muravyova, 2018).

At the same time, the results under scales determining behavioral-regulatory component show below-average scores: "Personal contribution to the city life" ( $M=11.74 ; \mathrm{SD}=2.07)$; "Planning of the future, which is connected with the city" $(\mathrm{M}=8.49 ; \mathrm{SD}=1.76)$. Therefore, the authors conclude that despite a quite positive emotional attitude of junior students to the city, they don't seek to participate in the city development. Perhaps, they find no senses yet and don't believe in the effectiveness of such actions; moreover, they still hesitate whether it is worth binding their further professional future with the city.

According to the results of the study of the social and psychological adaptation, the authors obtain the data which is demonstrated in table 2 . To conduct a comparative analysis, the study group was divided into two parts: group 1 - students who were born and still live in Kherson; group 2 - students who came from the countryside and small villages of the region to study at the university.

Based on the results of the study of the indicators of social and psychological adaptation, the authors establish statistically significant differences between two studied groups under an integrated index of the social and psychological adaptation "Adaptability" ( $\left.\mathrm{t}_{\text {емп. }}=7.96 ; \mathrm{p}<0.01\right)$. Thus, the general level of adaptation in social spheres of students of group 2, who came to Kherson from the countryside areas, is lower than of students who permanently reside in Kherson. In the light of the analysis of individual scales of Questionnaire of Social and Psychological Adaptation, the authors find statistically essential differences between groups under the scales "Self-perception" $\left(\mathrm{t}_{\text {емп. }}=5.94 ; \mathrm{p}<0.01\right)$ and "Emotional control" ( $\left.\mathrm{t}_{\text {емп. }}=7.30 ; \mathrm{p}<0.01\right)$ that confirms the occurrence of difficulties in the process of adaptation to the conditions of study at the university, the living conditions in the dormitory, the urban culture, rules and behavior standards of students who came to the city to study at the higher education institution. Besides, these challenges are experienced at the emotional level and affect the positivity of the perception of self-image. The conclusion is proved by the availability of statistically significant differences under the scale "Life satisfaction" $\left(\mathrm{t}_{\text {емп. }}=4.63 ; \mathrm{p}<0.01\right)$ where average indicator in
Водночас результати за шкалами, які визначають поведінково-регулятивний компонент, показали нижче за середні оцінки: “Особистий внесок у життя міста” (M = 11.74; SD = 2.07); “Планування майбутнього, яке пов'язане із містом" $(\mathrm{M}=8.49 ; \mathrm{SD}=1.76)$. Тобто, ми можемо зробити висновок про те, що у студентської молоді молодших курсів навчання при досить позитивному емоційному ставленні до міста, виявляється небажання брати особисто участь у розбудові міста, оскільки вони, мабуть, не бачать у цьому сенсу та не вірять в ефективність таких дій; крім того, вони ще сумніваються стосовно того, чи пов'язувати з цим містом своє подальше професійне майбутнє.

За результатами вивчення соціально-психологічної адаптації отримано дані, які представлено у таблиці 2.Для проведення порівняльного аналізу досліджувану групу розподілено на дві частини: група 1 - студенти, які народилися та продовжують жити у Херсоні; група 2 - студенти, які приїхали для навчання в університеті із сільської місцевості та невеличких містечок області.

На основі результатів дослідження показників соціально-психологічної адаптованості нами встановлено статистично значущі відмінності між двома групами досліджуваних за інтегральним показником соціально-психологічної адаптації “Адаптивність" ( $\left.\mathrm{t}_{\text {емп. }}=7.96 ; \mathrm{p}<0.01\right)$, тобто загальний рівень адаптації у соціальних сферах у студентів групи 2, які приїхали до Херсону із сільської місцевості є нижчим, ніж у тих студентів, які постійно проживають в Херсоні. За результатами аналізування по окремих шкалах “Опитувальника соціально-психологічної адаптації” з'ясовано наявність статистично значущих відмінностей між групами за шкалами “Самоприйняття" $\left(\mathrm{t}_{\text {емп. }}=5.94 ; \mathrm{p}<0.01\right)$ та "Емоційний комфорт" $\left(\mathrm{t}_{\text {емп. }}=7.30 ; \mathrm{p}<0.01\right)$, що доводить наявність складностей у процесі адаптації до умов навчання в університеті, до умов проживання у гуртожитку, до міської культури, правил та норм поведінки у студентів, які приїхали у місто для навчання у закладі вищої освіти. Причому, ці складності переживаються на емоційному рівні та торкаються позитивності сприйняття образу Я. Цей висновок підтверджується наявністю статистично значущих відмінностей за "Шкалою задоволеності життям" $\mathrm{t}_{\text {емп. }}=4.63$; $\mathrm{p}<0.01$ ), де середньоарифметичні показники у групі прибулих студентів $\epsilon$ нижчими, ніж у групі студентів, які народилися та живуть у Херсоні.

Водночас, слід зауважити, що за такими шкалами соціально-психологічної адаптації, як 
the group of non-resident students is lower than in the group of students who were born and live in Kherson.

At the same time, it should be emphasized that such scales of the social and psychological adaptation as "Acceptance of others", "Internality (internal control)", "The pursuit of dominance" don't show the statistically significant differences between the studied groups. The data is substantiated by the research findings of other domestic scientists (Andriychuk, 2018; Zavatska, 2012).

The obtained results of the differences in the level of social adaptation between the group of students, who were born, grew and live in Kherson, and a group of students who came to Kherson to study at the higher education institution encourage the authors to test a hypothesis on the possible influence of maturity of urban identity on the progress in the social and psychological adaptation of students.

To prove the synergies between the parameters of urban identity and indicators of the social and psychological adaptation, the authors use the correlation analysis. The results are presented in table 3.
"Прийняття інших", "Інтернальність (внутрішній контроль)", “Прагнення до домінування" не встановлено статистично значущих відмінностей між досліджуваними групами. Такі дані підтверджуються науковими результатами інших вітчизняних науковців (Андрійчук, 2018; Завацька, 2012).

Отримані нами результати про відмінності у рівні соціально-психологічної адаптації між групою студентів, які народилися, виросли та живуть в Херсоні, та групою студентів, які приїхали до Херсона навчатися у закладі вищої освіти, спонукали нас до перевірки гіпотези про можливий вплив сформованості міської ідентичності на успішність соціально-психологічної адаптації студентської молоді.

Задля доведення взаємозв'язку між параметрами міської ідентичності та показниками соціально-психологічної адаптації нами застосовано кореляційний аналіз. Результати представлено у таблиці 3.

Кореляційний аналіз показав наявність статистично значущих взаємозв'язків інтегральної шкали соціально-психологічної адаптації “Адаптивність" з такими показниками міської ідентичності: «Почуття належності до міста та віра в його можливості» $\left(\mathrm{r}_{\mathrm{s}}=.261 ; \mathrm{p}<0.05\right)$;

Table 3. Coefficients of indicators correlation of the urban identity and social-psychological adaptation ( $\mathrm{n}=67)$ Таблиця 3. Коефіцієнти кореляції показників міської ідентичності та соціально-психологічної адаптації $(\mathrm{n}=67)$

\begin{tabular}{|c|c|c|c|c|c|}
\hline $\begin{array}{c}\text { Scale name } \\
\text { Назва шкал }\end{array}$ & 1 & 2 & 3 & 4 & 5 \\
\hline $\begin{array}{c}\text { Adaptability } \\
\text { Адаптивність }\end{array}$ & $0.261 *$ & $0.272^{*}$ & 0.194 & $0.259 *$ & 0.185 \\
\hline $\begin{array}{c}\text { Self acceptance } \\
\text { Самоприйняття }\end{array}$ & 0.127 & 0.201 & 0.006 & 0.185 & 0.154 \\
\hline $\begin{array}{l}\text { Acceptance of others } \\
\text { Прийняття інших }\end{array}$ & $0.301 *$ & 0.142 & 0.159 & 0.163 & 0.129 \\
\hline $\begin{array}{c}\text { Emotional comfort } \\
\text { Емоційний комфорт }\end{array}$ & $0.324 *$ & $0.338^{* *}$ & 0.146 & $0.257^{*}$ & 0.102 \\
\hline $\begin{array}{c}\text { Internality } \\
\text { Інтернальність }\end{array}$ & 0.132 & 0.149 & 0.116 & $0.264^{*}$ & $0.296^{*}$ \\
\hline $\begin{array}{l}\text { The pursuit of dominance } \\
\text { Прагнення до домінування }\end{array}$ & 0.108 & 0.067 & 0.105 & 0.131 & 0.172 \\
\hline $\begin{array}{c}\text { Life satisfaction } \\
\text { Задоволеність життям }\end{array}$ & 0.004 & 0.195 & 0.178 & $0.273 *$ & 0.153 \\
\hline
\end{tabular}

Note: ${ }^{*}-\mathrm{p}<0.05 ;^{* *}-\mathrm{p}<0.01 ; 1$. Belonging to the city and belief in its opportunities; 2 . Emotional attachment and feeling of closeness; 3 . A city which has a unique nature; 4 . Personal contribution to the city life; 5 . Planning of the future, which is connected with the city.

Примітка: * - p $<0,05 ; * *-p<0,01 ; 1$. Почуття належності до міста та віра в його можливості; 2 . Емоційна прив'язаність та почуття близькості; 3. Місто, яке має унікальність; 4. Особистий внесок у життя міста; 5. Планування майбутнього, яке пов'язане із містом. 
The correlational analysis shows the availability of statistically significant interrelations of the integral scale of the social and psychological adaptation "Adaptability" with such indicators of the urban identity as "Belonging to the city and belief in its opportunities" ( $\mathrm{rs}=.261$; $\mathrm{p}<$ 0.05); "Emotional attachment and feeling of closeness" $\left(r_{s}=.272 ; \mathrm{p}<0.05\right)$; "Personal contribution to the city life" $\left(r_{s}=.259 ; \mathrm{p}<0.05\right)$. The results confirm the fact that a person who has a high level of the social and psychological adaptability in the social environment and simultaneously a positive attitude to this environment (in this study it refers to the city of residence) feels his belonging to the city, i.e. he has an activated feeling "we"; moreover, the students are ready to make efforts to improve the city.

The indicator of the social and psychological adaptation "Acceptance of others" correlates with the scale of urban identity "Belonging to the city and belief in its opportunities" $\left(\mathrm{r}_{\mathrm{s}}=.301 ; \mathrm{p}<0.05\right)$, i.e. a positive attitude to people from the nearest micro-society is associated with a positive attitude to the community the students relate to.

The scale "Emotional comfort" demonstrates the following correlational interrelations: "Belonging to the city and belief in its opportunities" $\left(\mathrm{r}_{\mathrm{s}}=.324 ; \mathrm{p}<0.05\right)$; "Emotional attachment and feeling of closeness" $\left(r_{s}=.338 ; p<0.01\right)$; "Personal contribution to the city life" $\left(r_{s}=.257 ; p<0.05\right)$. In other words, awareness of the city, emotional attitude and attachment to the city mainly determine the emotional comfort of students. However, it is worth mentioning that students express a certain readiness for positive practices for the benefit of the city where they live in now.

The preliminary conclusion is supported by the statistically significant correlations of "Internality (internal control)" with behavioral-regulatory indicators of urban identity "Personal contribution to the city life" $\left(r_{\mathrm{s}}=.264 ; \mathrm{p}<0.05\right)$; "Planning of the future, which is connected with the city" $\left(\mathrm{r}_{\mathrm{s}}=.296 ; \mathrm{p}<0.05\right)$. One can state that a person, who takes responsibility for the events that happen to him and for their consequences, turns focus to improve his residence place and believes that his actions make sense and effectiveness.

The correlation between "Satisfaction with Life Scale" of E. Diener and the indicator of the social and psychological adaptation "Personal contri-
“Емоційна прив'язаність та почуття близькості” ( $\left.\mathrm{r}_{\mathrm{s}}=.272 ; \mathrm{p}<0.05\right) ;$ “Особистий внесок у життя міста" $\left(\mathrm{r}_{\mathrm{s}}=.259\right.$; $\left.\mathrm{p}<0.05\right)$. Такі результати підтверджують, що особистість, яка має високий рівень соціально-психологічної адаптованості у соціальному середовищі, водночас має позитивне ставлення до цього середовища (у нашому дослідженні - до міста проживання), відчуває свою належність до міста, тобто має сформоване почуття "ми", крім того, студенти готові докладати зусиль до того, щоб покращити своє місто.

Показник соціально-психологічної адаптації "Прийняття інших" корелює зі шкалою міської ідентичності «Почуття належності до міста та віра в його можливості» $\left(\mathrm{r}_{\mathrm{s}}=.301 ; \mathrm{p}<0.05\right)$, тобто позитивне ставлення до людей з найближчого мікросоціуму пов'язано з позитивним ставленням до спільноти, в якій зараз перебувають студенти.

Шкала "Емоційний комфорт" показала такі кореляційні взаємозв'язки: «Почуття належності до міста та віра в його можливості» $\left(\mathrm{r}_{\mathrm{s}}=.324 ; \mathrm{p}<0.05\right)$; “Емоційна прив'язаність та почуття близькості" $\left(\mathrm{r}_{\mathrm{s}}=.338\right.$; $\left.\mathrm{p}<0.01\right)$; "Особистий внесок у життя міста" $\left(\mathrm{r}_{\mathrm{s}}=.257\right.$; $\left.\mathrm{p}<0.05\right)$, тобто поінформованість про місто, емоційне ставлення та прив'язаність до міста переважно зумовлюють емоційний комфорт студентської молоді. Хоча слід відзначити й те, що студенти виявляють певну готовність до реальних справ на благо міста, в якому вони зараз живуть.

Цей попередній висновок підтверджується наявністю статистично значущих кореляційних зв”язків “Інтернальності (внутрішнього контролю)" 3 поведінково-регулятивними показниками міської ідентичності «Особистий внесок у життя міста» $\left(\mathrm{r}_{\mathrm{s}}=.264 ; \mathrm{p}<0.05\right)$; "Планування майбутнього, яке пов'язане з містом" $\left(\mathrm{r}_{\mathrm{s}}=.296\right.$; $\left.\mathrm{p}<0.05\right)$. Можна зазначити, що особистість, яка відчуває власну відповідальність за події, які з нею відбуваються, та за їх наслідки, спрямовує власну активність на покращення місця свого перебування та вважає, що іï дії мають сенс та ефективність.

Цікавим виявився кореляційний зв'язок між “Шкалою задоволеності життям” Е. Дінера та показником соціально-психологічної адаптації «Особистий внесок у життя міста» $\left(\mathrm{r}_{\mathrm{s}}=.296 ; \mathrm{p}<0.05\right)$. На наш погляд, це свідчить про те, що коли людина вже обрала своє місто та задоволена перебуванням у ньому, вона готова вкладати свою працю у розвиток міста проживання; позитивні результати, у свою чергу, підвищують цю задоволеність. 
bution to the city life" $\left(\mathrm{r}_{\mathrm{s}}=.296 ; \mathrm{p}<0.05\right)$ proves interesting. In the authors' standpoint, the above substantiates that if a person has chosen the city, he/she is ready to put out energies in the development of the city of residence, and positive results, in turn, increase the satisfaction.

\section{Conclusions.}

1) The research finds out that urban identity is the outcome of the process of social categorization, which is based on an individual's belonging to the urban community that leads to the assimilation of norms, rules, standards of behavior which are peculiar to the typical urbanite.

2) The authors determine the differences in the parameters of social and psychological adaptation in the social sphere, i.e. in the scales "self-perception", "emotional comfort", "satisfaction with life", between the group of students who were born, grew and live in the city and the group of students who came to the city from small towns or villages of the region to study at the higher education institution $(\mathrm{p}<0.01)$.

3 ) It is established the availability of interrelations between the parameters of urban identity and indicators of the social and psychological adaptation of students that justifies the influence of mature urban identity (of cognitive, emotional, behavior-regulatory components) on the effectiveness of the social and psychological adaptation in the city. The article proves that progress in the city adaptation conditioned by the belonging to the city and belief in its opportunities, the emotional attachment and closeness to the city.

4) The process of adaptation has its difficult periods associated with stress rise during the development of urban identity, and this fact requires the creation of special training programs which help non-resident students to adapt in the city and promote a tolerant attitude of urbanites to newcomers that may be a prospect for further research.

\section{References}

Andriychuk, I. P. (2018). Features of adaptation of students - future psychologists to higher education. International Journal of Innovative Technologies in Social Science, 4(8),Vol. 2. DOI: https://doi. org/10.31435/rsglobal_ijitss/01062018/5702

Baranova, V. A. (2012). Urban and rural societies: socio-psychological aspects of the study of territorial-settlement communities. Bulletin of St. Petersburg State University. Series 12, 2. 194-201.

\section{Висновки}

1) 3'ясовано, що міська ідентичність $\epsilon$ результатом процесу соціальної категоризації, основою для якої $\epsilon$ належність людини до міської спільноти, що призводить до засвоєння норм, правил, стандартів поведінки, які $\epsilon$ характерними для типового містянина.

2) Визначено наявність відмінностей за параметрами соціально-психологічної адаптації у соціальній сфері, а саме, за шкалами "самоприйняття", "емоційний комфорт”, “задоволеність життям", між групою студентів, які народилися, виросли та проживають зараз у місті, та групою студентів, які приїхали у місто для навчання у закладі вищої освіти із невеликих містечок та сіл області $(\mathrm{p}<0,01)$.

3) Встановлено наявність взаємозв'язків між параметрами міської ідентичності та показниками соціально-психологічної адаптації студентської молоді, що доводить вплив сформованої міської ідентичності (когнітивного, емоційного, поведінково-регулятивного компонентів) на ефективність соціально-психологічної адаптації у місті. Доведено, що успішність адаптації у місті зумовлена почуттям належності до міста та вірою в його можливості, емоційною прив'язаністю та почуттям близькості до міста.

4) Процес адаптації має свої складні періоди, що пов'язані з підвищенням напруженості при розвитку міської ідентичності, і це потребує створення спеціальних тренінгових програм, які допомагають в адаптації приїжджих студентів до умов міста, та сприяють розвитку толерантного ставлення жителів міста до прибулих, що може бути перспективою подальших досліджень.

\section{Список використаних джерел}

Андрійчук I. П. Особливості адаптації студентів майбутніх психологів до навчання у вищій школі. International Journal of Innovative Technologies in Social Science. 4(8), Vol. 2, June 2018 DOI: https://doi.org/10.31435/rsglobal_ ijitss/01062018/5702

Баранова В. А. Городской и сельский социумы: социально-психологические аспекты исследования территориально-поселенческих общностей. Вестник СПбГУ. Сер. 12. 2012. Вып. 2. C.194-201.

Belanche D., Casalys L. V., Flavian C. Understanding the cognitive, affective and evaluative components of social urban identity: Determinants, measurement, and practical consequences. Journal of Environmental Psychology. 2017. Vol. 50. P. 138-153. 
The features of the influence of urban identity on the social and psychological adaptation of students
Belanche, D., Casalys, L. V. \& Flavian, C. (2017). Understanding the cognitive, affective and evaluative components of social urban identity: Determinants, measurement, and practical consequences. Journal of Environmental Psychology, 50. 138-153. DOI: https://doi.org/10.1016/j.jenvp.2017.02.004

Bernardo, F. \& Palma-Oliveira, J. M. (2013). Place identity, place attachment and the scale of place: the impact of places alience. Psychology, 4. 167-193. DOI: https://doi.org/10.1080/21711976.2013.107 73867

Blynova, O. Ye, Popovych, I. S., Bokshan, H. I., Tsilmak, O. M. \& Zavatska, N. Ye. (2019). Social and Psychological Factors of Migration Readiness of Ukrainian Students. Revista ESPACIOS, 40(36). 4.http:// www.revistaespacios.com/a19v40n36/19403604. html

Blynova, O. Ye. (2018). Psychological aspects of the adaptation of rural residents to urban conditions. Actual problems of personality psychology and social interaction: collection of scientific articles. Grodno: Grodnenskij gosudarstvennyj universitet imeni Janki Kupaly. 24-31.

Dias, P. \& Ramadier, T. (2015). Social trajectory and socio-spatial representation of urban space: The relation between social and cognitive structures. Journal of Environmental Psychology, 41. 135-144. DOI: https://doi.org/10.1016/j.jenvp.2014.12.002

Dyagileva, N. S. \& Zhuravleva, L. A. (2012). Urban identity: concept, structure, fundamentals. Sociology of the city, 1. 46-61.

Hubeladze, I. H. (2015). Rural youth in the city: the search for identity: a monograph. Kyiv: Milenium.

Litvinova, S. A., Muravyova, O. I. (2019). City identity questionnaire: development, validation, reliability verification. Bulletin of the Novosibirsk State Pedagogical University, 8(1). 71-93. DOI: 10.15293/22263365.1801 .05

Miklyaeva, A. V. \& Rumyanceva, P. V. (2011). The ratio of central and peripheral components in the structure of social identity. Psychological Journal, 32(5). 36-45.

Milgram, S. (2000). Experiment in social psychology. SPb.: Piter.

Osin, E. N.\& Leontiev, D. A. (2008). Testing Russian-languageversions of two scales of rapid assessment of subjective well-being. Materials of the III All-Russian Sociological Congress, Moscow. Institute of Sociology RAS.

Osnytsky, A. K. (2004). Characterization of social adaptation. Psychology and school, 1. 43-56.

Shtejnbah, H. E. \& Elensky, V. I. (2004). Psychology of Living Space. SPb.: Rech.

Ujanga, N. \& Zakariya, K. (2015). The notion of place, place meaning and identity in urban regeneration. Procedia - social and behavioral sciences, 170, 709-717. DOI: http://dx.doi.org/10.1016/j. sbspro.2015.01.073

Zavatska, N. Ye. (2012). Sociocultural and psychological aspects of personality adaptation in contemporary society: a monograph. Luhansk: Vyd-voim. V. Dalia.
DOI: https://doi.org/10.1016/j.jenvp.2017.02.004 Bernardo F., Palma-Oliveira J. M. Place identity, place attachment and the scale of place: the impact of place salience. Psychology. 2013. Vol. 4. P. 167193. DOI: https://doi.org/10.1080/21711976.201 3.10773867

Blynova, O. Ye, Popovych, I. S., Bokshan, H. I., Tsilmak, O. M. \& Zavatska, N. Ye. (2019). Social and Psychological Factors of Migration Readiness of Ukrainian Students. Revista ESPACIOS, Vol. 40. (№ 36). Page 4.

h t t p : / / w w w.revistaes pacios.com / a19v40n36/19403604.html

Блинова Е. Е. Психологические аспекты адаптации сельских жителей к условиям городской среды. Актуальные проблемы психологии личности и социального взаимодействия : сб. науч. ст. / ГрГУ им. Я. Купалы ; науч. ред.: А. В. Ракицкая, О. Г. Митрофанова. - Гродно : ГрГУ, 2018. С.24-31.

Dias P., Ramadier T. Social trajectory and socio-spatial representation of urban space: The relation between social and cognitive structures. Journal of Environmental Psychology. 2015. Vol. 41. P. 135-144. DOI: https://doi.org/10.1016/j. jenvp.2014.12.002

Дягилева Н. С., Журавлева Л. А. Городская идентичность: понятие, структура, основы. Социология города. 2012. № 1. С. 46-61.

Губеладзе I. Г. Сільська молодь у місті: пошук ідентичності : монографія. К. : Міленіум, 2015. $236 \mathrm{c}$.

Литвинова С. А., Муравьева О. И. Опросник идентичности с городом: разработка, валидизация, проверка надежности. Вестник Новосибирского государственного педагогического университета. 2018. Том. 8. №1. C. 71-93. DOI: 10.15293/2226-3365.1801.05

Микляева А. В., Румянцева П. В. Соотношение центральных и периферических компонентов в структуре социальной идентичности личности. Психологический журнал. 2011, том 32, № 5, С. 36-45.

Милграм С. Эксперимент в социальной психологии. СПб. : Питер, 2000. 336 с.

Осин Е. Н., Леонтьев Д. А. Апробация русскоязычных версий двух шкал экспресс-оценки субъективного благополуччя. Материалы III Всероссийского социологического конгресса. М.: Институт социологии РАН, Российское общество социологов, 2008. [Диск CD, ISBN 9786- 89697-157-3.]

Осницкий А. К. Определение характеристик социальной адаптации. Психология и школа. 2004. № 1. С. 43-56.

Штейнбах Х. Э., Еленский В. И. Психология жизненного пространства. СПб. : Речь, 2004. $239 \mathrm{c}$.

Ujanga N., Zakariya K. The notion of place, place meaning and identity in urban regeneration. Procedia - social and behavioral sciences. 2015. Vol. 170. P. 709-717. DOI: http://dx.doi.org/10.1016/j. sbspro.2015.01.073

Завацька Н. Є. Соціокультурні та психологічні аспекти адаптації особистості в сучасному соціумі: монографія / Під ред. Н. Є. Завацької. Луганськ: Вид-во ім. В. Даля, 2012. 320 с. 